\title{
Implementations of Autonomous Maintenance to Relieve Stoppages on PT NIKF - Sachet Packaging Chain
}

\author{
Sukanta $^{1}$, R Maulana ${ }^{1}$, Dessy Agustina Sari ${ }^{2}$
}

\begin{abstract}
Autonomous maintenance taught operator to keep devices, create cooperation each employer and did problem solving that occurring in machine. This research described assembling of autonomous maintenance on PT NIKF - minor stoppages trouble in sachet production line. Our team used the OEE method to know the latest line condition and variety losses that causing the performance were not optimal. After that, the next steps were using visual losses map and diagram Pareto to get the detail (component with many losses). By Go See Think Do, the researcher could find much maintenance that must be done in SIC line 1. Through the application, this effort could reduce the losses of minor stoppages $\mathbf{- 7 9 , 5 2 \% .}$
\end{abstract}

Keywords-Minor stoppages, go see think do.

\section{INTRODUCTION}

$\mathrm{M}$ aintenance goal in device aspect of manufacture industry was improvement effectiveness or optimality of equipment or machine. In reality, effort for the repairing was often an only wasting because it did not relate the main set of problems. Team for this did not get clearly plus truth of the trouble and factor agents. In Infant Cereal Plant, sachet line of Chain 1 (SIC line 1) still was found some question such as high percentage of engine damage (breakdown and or minor stoppages). This happen caused uncomplete the company target and Figure 1 showed that asset intensity of SIC line 1 in 2016 was still acceptable. It was one of many key performance indicators (KPI) in PT NIKF that indicating capability a machine or line to do production process.

The figure also defined that the factory might make definition and new concept from their upgrading system. The both things were not only able to enactive belong equipment (produce Good Finish) but also it could too measure globally efficiency, matter identify, and give improvement idea that might be done. Through that, autonomous maintenance (AM) design could be a solution in this company. AM was part of Total Productivity Maintenance (TPM) program. This method also used Global Trans Energy Global to get information all of condition and reduce waiting time to increase operational effectiveness in ship (fleet)[1].

So on implementation, it included many sides production sectors. Researcher (Singh, Gohil, Shah, \& Desai, 2013) statement that success of TPM depended on 5-S, Jishu Hozen, planned maintenance, quality maintenance, Kaizen, office TPM and safety, health and environment. One of the purposes was to increase knowledge and skill about production. Then, machine treatment for employer would too give positive affect.

\section{METHOD}

Methodology that used this research was resumed in Figure 2.

\footnotetext{
${ }^{1}$ Sukanta and $\mathrm{R}$ Maulana are with Departement of Industrial Engineering, University of Singaperbangsa Karawang, Karawang West Java, 41361, Indonesia. Email: sukanta@staff.unsika.ac.id

${ }^{2}$ Dessy Agustina Sari is with Departement of Electrical Engineering, University of Singaperbangsa Karawang, Karawang - West Java, 41361, Indonesia.
}

\section{RESUlTS AND DiscUSSION}

\section{A. Measuring of Overall Equipment Effectiveness}

The OEE point could show the latest situation in SIC line 1 and performance all of the equipment that losing could be pushed. This way also acted as image performance from day to day and as tools in continuous improvement program for manufacturing industry [2] and supported by supply of necessary resources [3]. Data that given was weekly outlet OEE on 1st until 31 st 2016 years, see Figure $3-6$. This research gave estimation of availability, performance, and quality ratio with each its formula.

$$
\begin{aligned}
& \text { B. Availability Ratio }(A R) \\
& \text { Availability Ratio }=\frac{\text { Operating Time }}{\text { Loading Time }} \times 100 \% \\
& A R=\frac{\text { Loading Time }- \text { Unplanned Stoppages }}{\text { Production Time }- \text { Planned Stoppages }} \\
& \text { AR }=\frac{(6997,2-1490,4) \text { minutes }}{(7680-682,8) \text { minutes }} \times 100 \% \\
& \text { AR }=\frac{5506,8}{6997,2} \times 100 \% \sim 78,70 \%
\end{aligned}
$$

\section{Performance Ratio (PR)}

Cycle time was time that needed to produce one card board box (CB) and the research was based on field data. Sachet product that resulted each minute was 50 items. Every CB was consist of 16 slender so it that outcome per minute was 3,125 (50 per 16) and percentage of performance ratio in first week was this below.

$$
\begin{aligned}
\mathrm{PR} & =\frac{\text { Output } \times \text { Cycle Time }}{\text { Operating Time }} \times 100 \% \\
\mathrm{PR} & =\frac{17.117 \times 1 \text { minute }}{3,125 \mathrm{CB} \times 5506,8} \times 100 \% \\
\mathrm{PR} & =99,47 \%
\end{aligned}
$$

\section{Quality Ratio}

$$
\begin{aligned}
& \text { Quality Ratio }=\frac{\text { Output }- \text { Total Defect }}{\text { Output }} \times 100 \% \\
& \text { Quality Ratio }=\frac{(17.117-77,75) \mathrm{CB}}{(17.117) \mathrm{CB}} \times 100 \%
\end{aligned}
$$




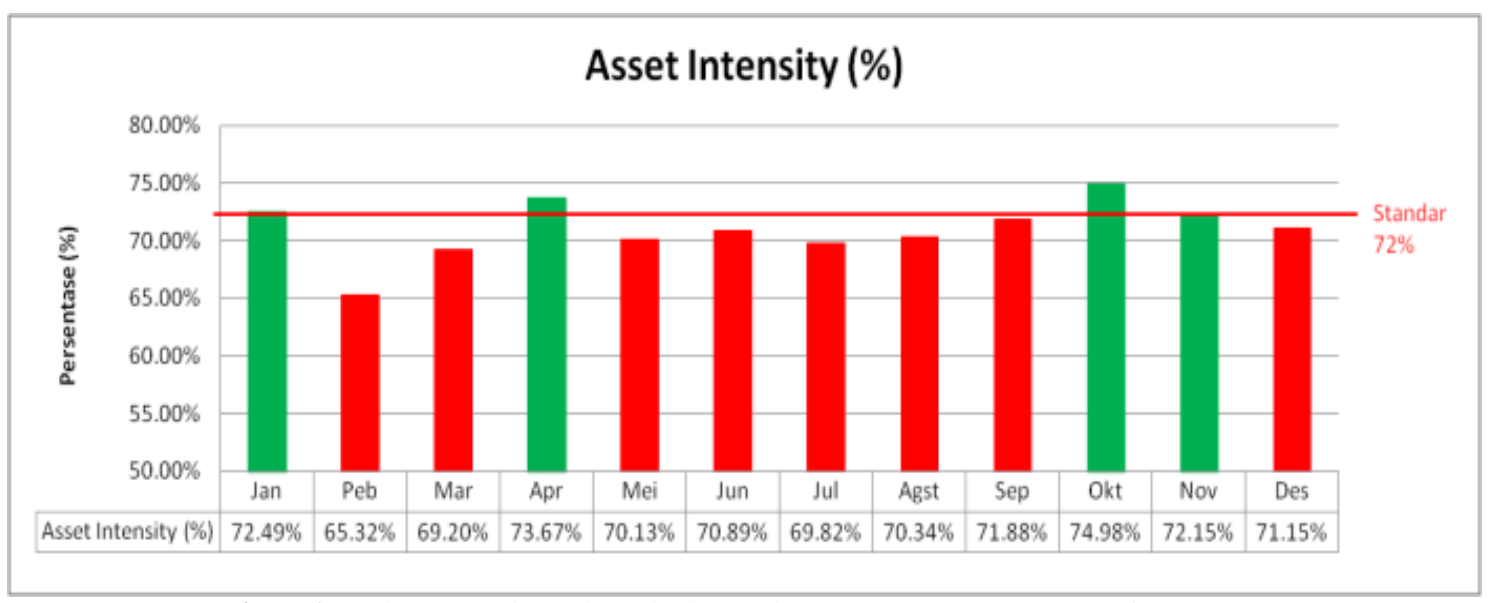

Figure 1. Achievement of asset intensity in SIC line 1 (source by annual report of PT NIKF).

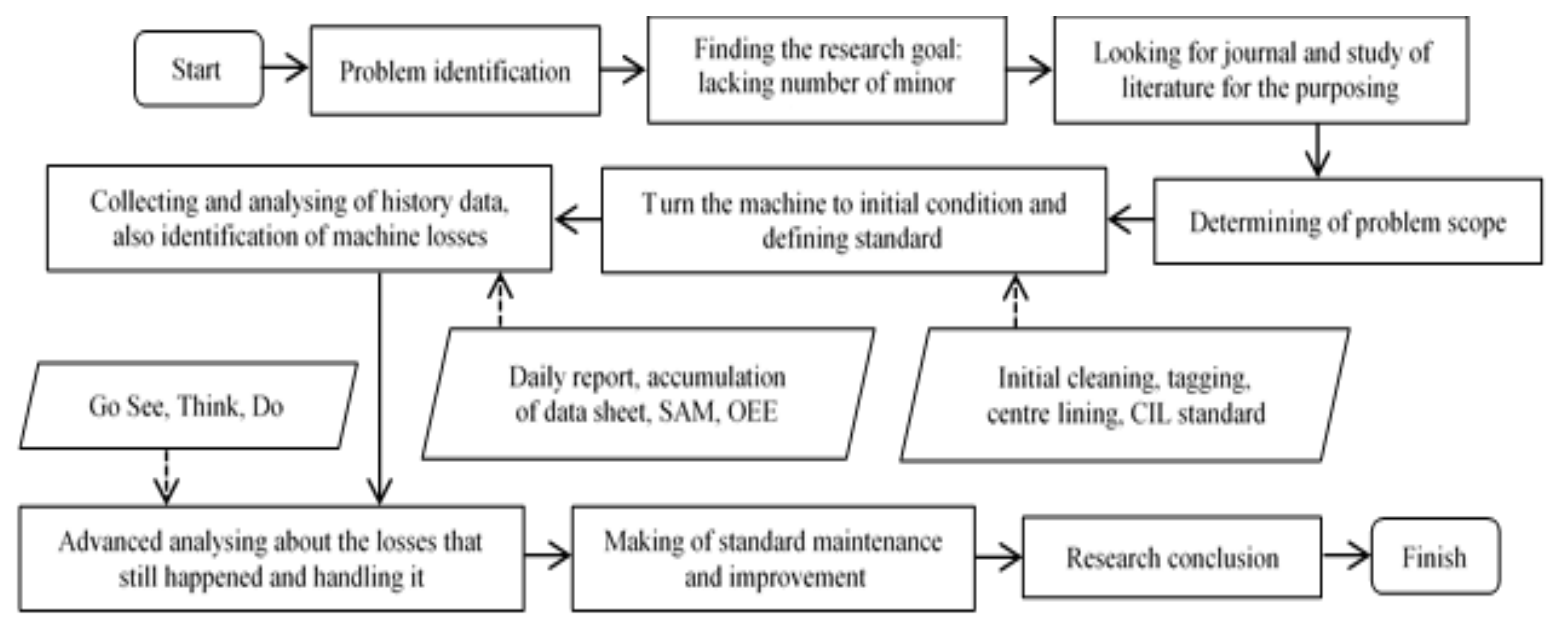

Figure 2. Flowchart of research method.

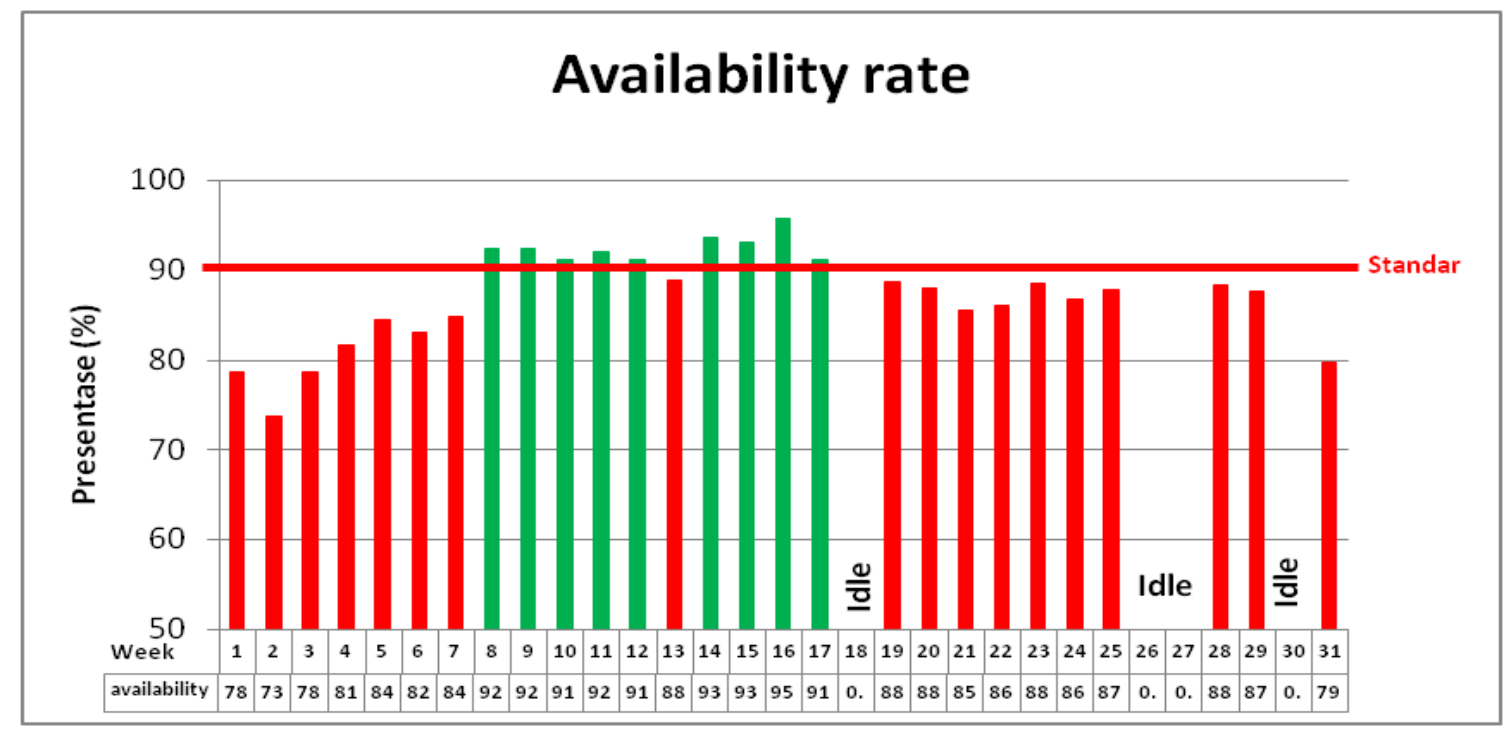

Figure 3. Trend of availability ratio point

Quality Ratio $=99,55 \%$

After that, accounting of OEE used this equation $\mathrm{OEE}=$ Availability Ratio $\times$ Performance Ratio

$$
\times \text { Quality Ratio }
$$

$\mathrm{OEE}=78,70 \% \times 99,47 \% \times 99,55 \%$

$\mathrm{OEE}=77,92 \%$

Achievement of OEE in SIC line 1 still often did not reach the standard score. The world class manufacturing
OEE was $85 \%$ [4]. By the estimation, low of availability point was failure $-78,70 \%$. It should be $90 \%$. Highly unplanned stoppages were $21.9333,93$ minutes for 31 st and 1.668 minutes in last week. The both of reasons also supported the existing trouble. So, the researchers would fix the effectiveness of machine by reducing amount of unplanned stoppages. Another researcher gave a statement that the OEE tool could help to optimize the performance of existing capacity [5]. OEE score 63-79\% indicated that experiment had improvement in productivity and quality of product [3]. 


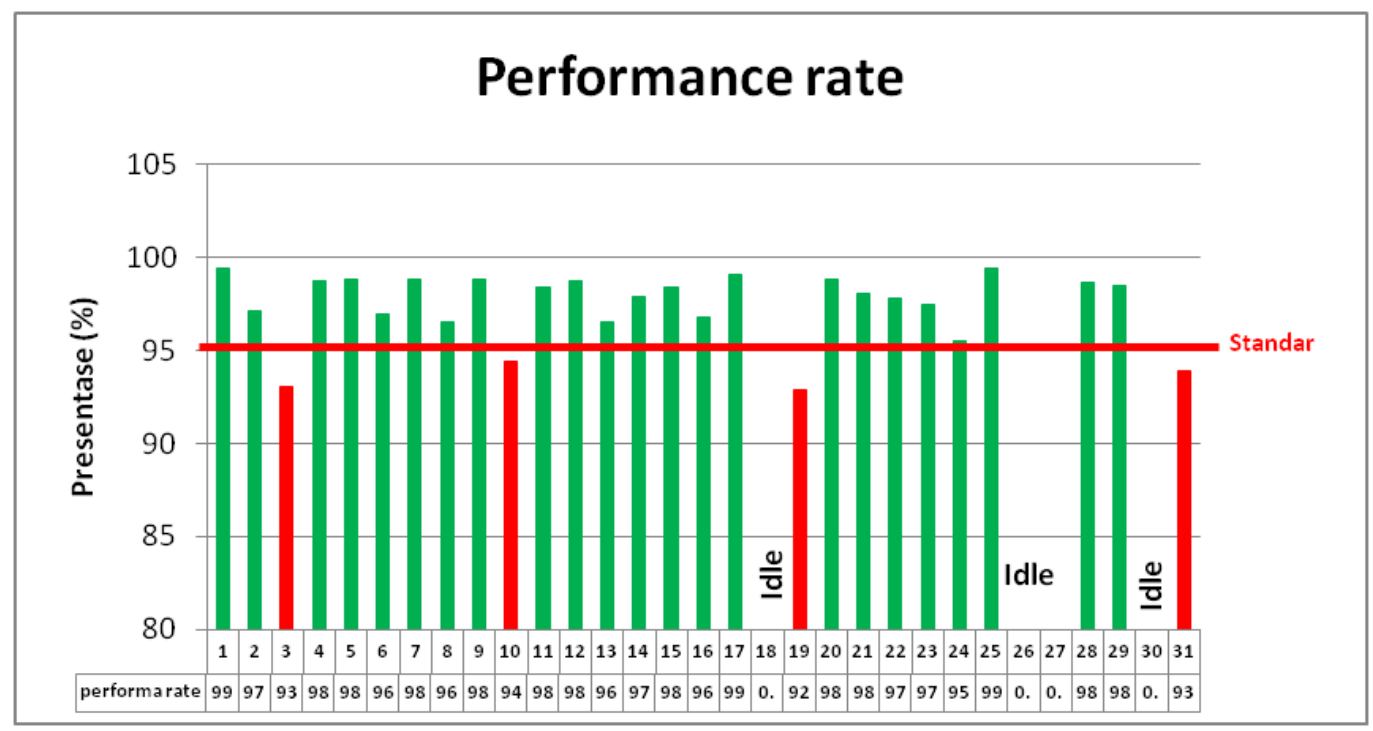

Figure 4. Preference of performance rate.

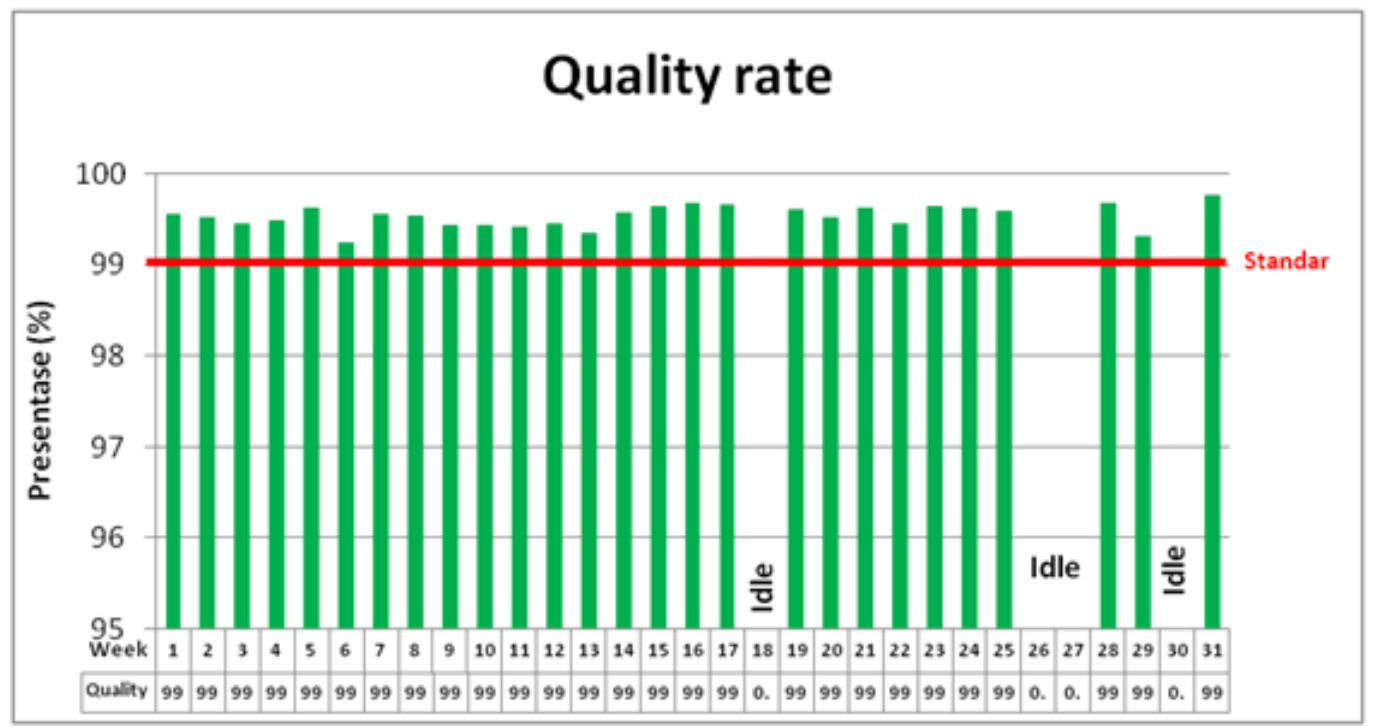

Figure 5. Inclination of quality ratio.

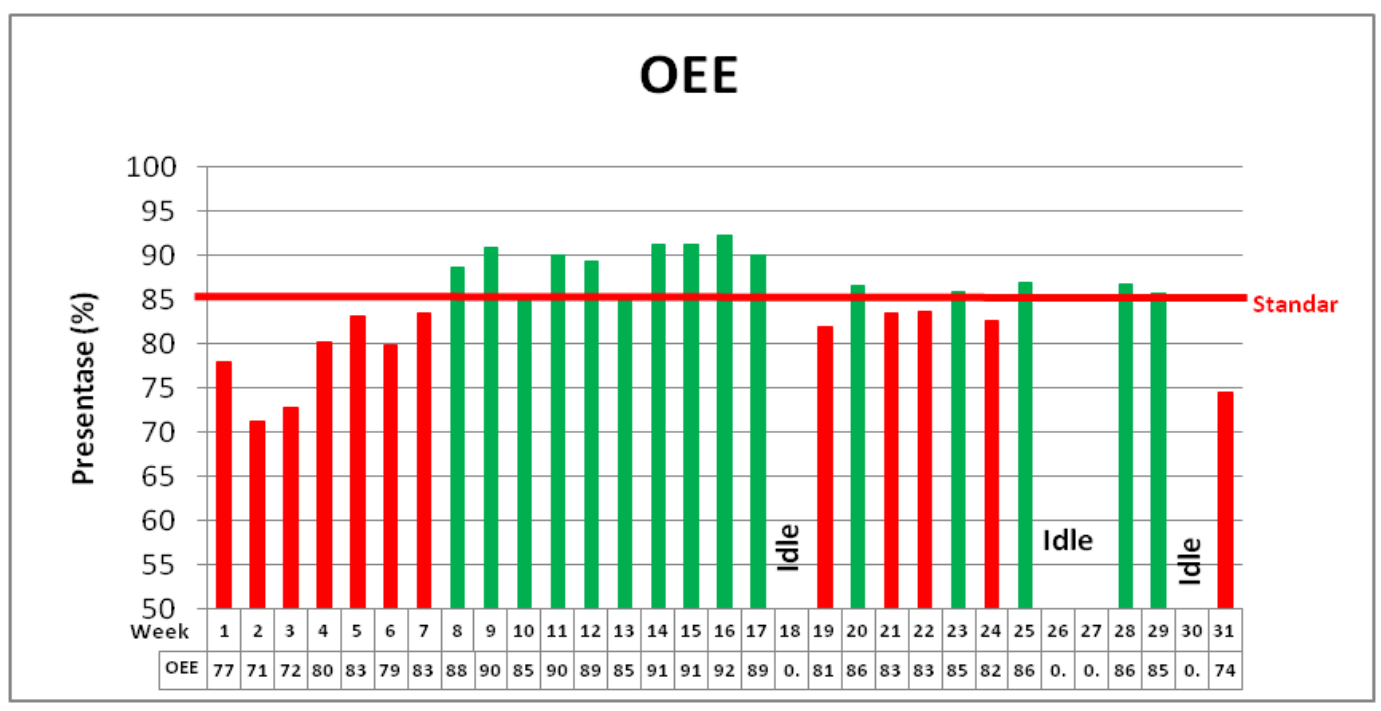

Figure 6. Trend of OEE score.

\section{Time and Venue Stoppages}

The researchers used Visual Loss Mapp to guide where and how long stoppages. Data that needed was stoppages data from SAM software for 3 months (May - July, 17th to 31 st week, see Figure 7 below). The image explained that the biggest problem was minor stoppages in packing area such as sachet jammed in 2nd formation unit (2059 minutes, 624 times) and 1st was 1619 minutes, 506 times. Next, in 1 st and 2nd folding unit were 465,85 -265 and 266,85 minutes --198 times consecutively. 


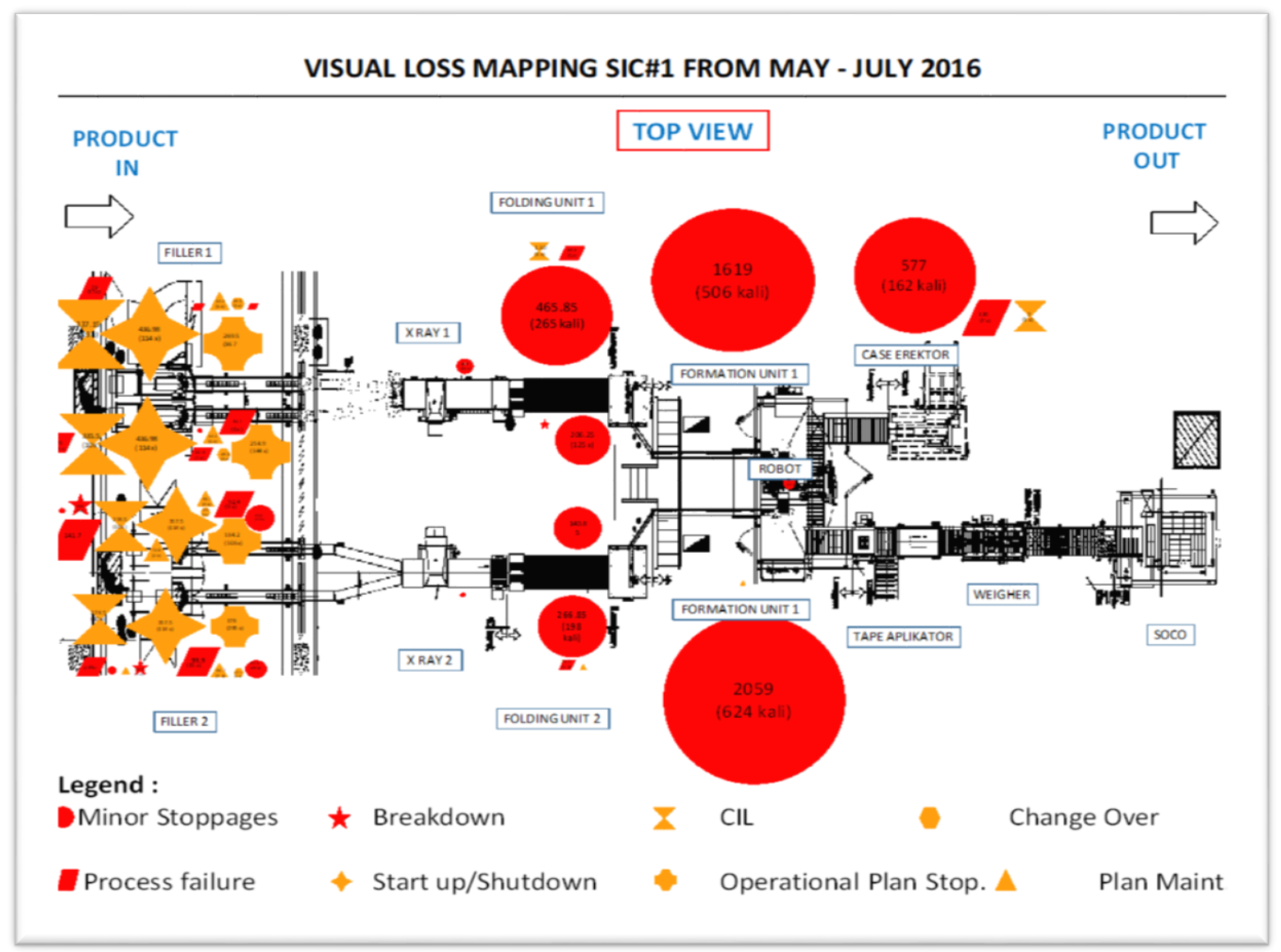

Figure 7. Outlet visual loss map in SIC line 1 in May - July (Source: stoppages analysis modulus - SAM in SIC line 1).

Based on Figure 7, the researcher pulled the data in 31 st week to know the newest condition in SIC line 1. Pareto diagram was given in Figure 8 to review and understand minor stoppages in last time.

Figure 8 showed that two machine component that donating higher minor stoppages was 1st and 2nd formation unit, $64 \%$ and $29,72 \%$ in Folding $1 \& 2$ Unit. So high condition (almost 93,78\%) could be certain that the both tools got improvement. Analysing to the component utilized Go See Think Do (GSTD) way to find out the question source and then fixing treatment.

\section{E. Presence Analysis of Minor Stoppages}

Next way was to handle the existed problem that found out from the processing data. It was minor stoppages that still being present in component of formation and folding unit - jammed sachet. The best treatment exploited an instrument. It was Go See Think Do (GSTD) that usually utilized to break the daily matter. GSTD could help user to get the trouble source that be on going (Gemba) and resumed in Table 1-3 and Figure 9 for the Formation 1 and 2 Unit), and Table 4-6 and Figure 10 for the Folding 1 and 2 Unit.

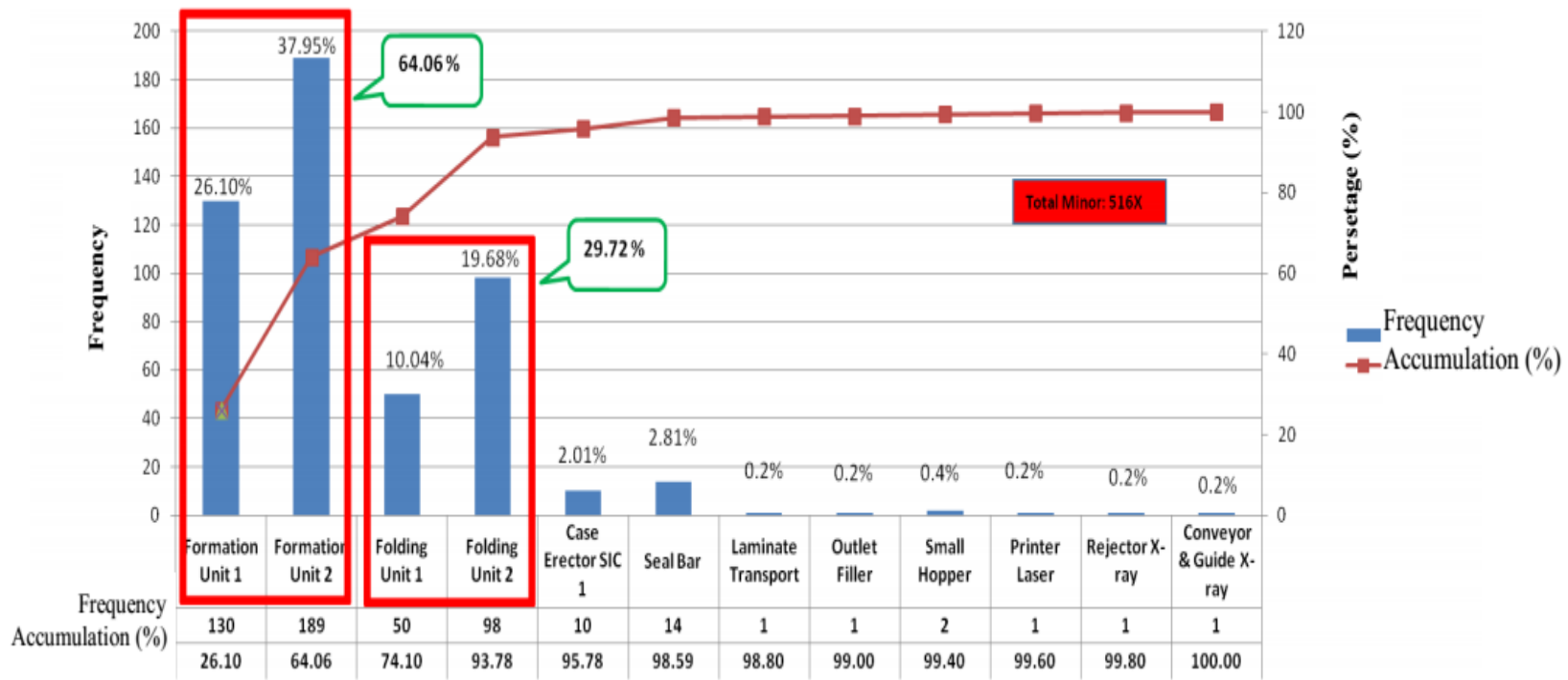

Figure 8. Pareto diagram of minor stoppages in SIC line 1 - 31st week. 
F. GSTD to Minor Stoppages on Formation 1 and 2 Unit

1. Go See

TABLE 1.

GO SEE TO MINOR STOPPAGES IN FORMATION 1 AND 2 UNIT

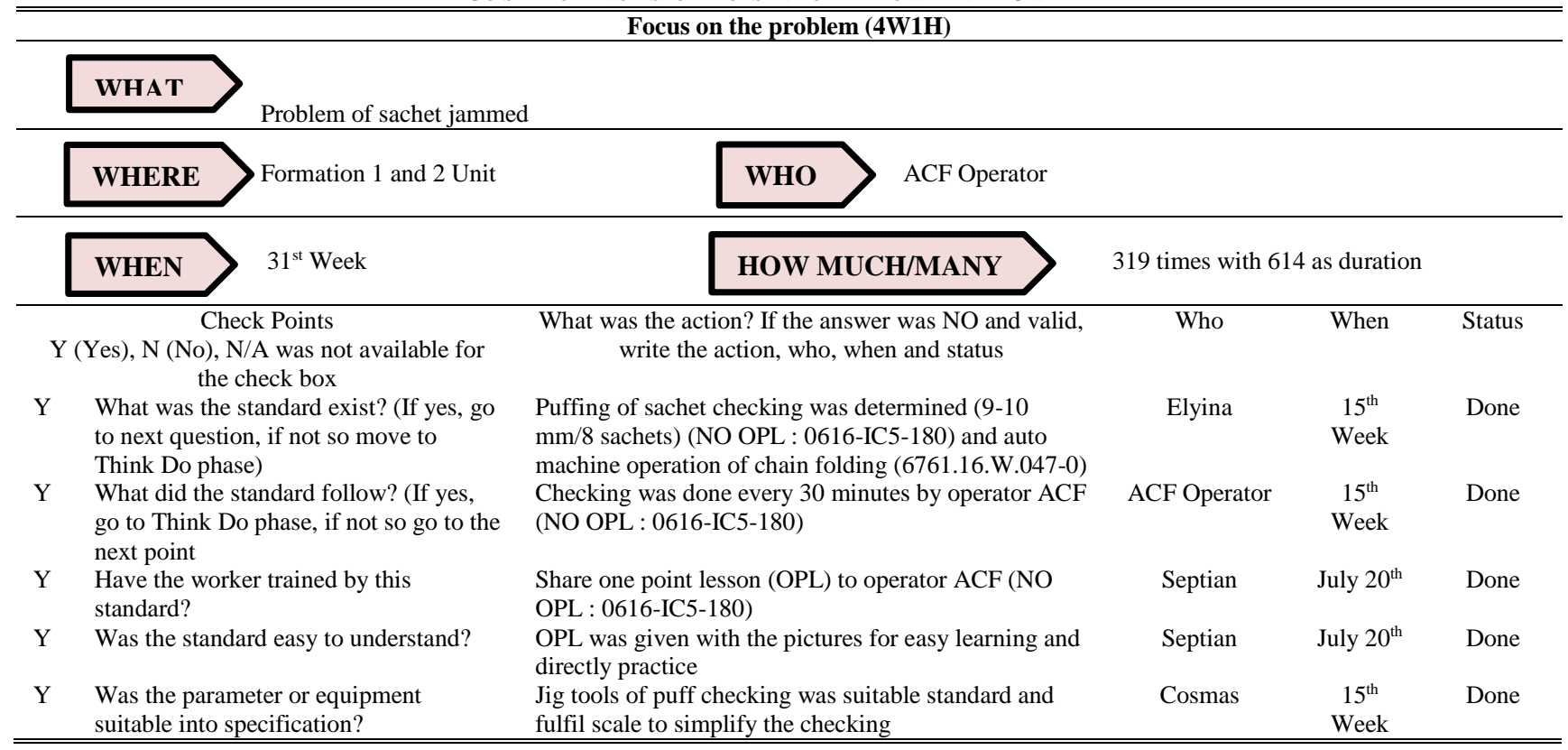

\section{Think}

After founded the existed problem and standard investigation still happened so next ways was looking for the cause by thinking point. It was done through group brainstorming to get possible cause. In this stage, the researcher used device - fishbone and 5WHY analysis (Figure 9 and Table 2). Figure 9 showed that the matters were $\mathrm{J}, \mathrm{L}, \mathrm{M}$, and $\mathrm{N}$.

$\mathrm{A}=$ case did not open, $\mathrm{B}=$ soon vacuum in robot was hard, $\mathrm{C}=$ parameter of stopper plate had changed, $\mathrm{D}=$ puffing device was not calibrated, $\mathrm{E}=$ conveyor installation of formation unit was wrong, $\mathrm{F}=$ how to pair magazine case was wrong, $\mathrm{G}=$ standard cleaning was not exist yet, $\mathrm{H}=$ area of formation unit was slippery, $\mathrm{I}=$ area of formation unit was dirty, $\mathrm{J}=$ sensor did not detect sachet, $\mathrm{K}=$ loss vacuum in robot, $\mathrm{L}=$ tip of the sachet stuck in finger pusher, $\mathrm{M}=$ end of the sachet stuck in sensor hole, $\mathrm{N}=$ sachet left in separation unit, $\mathrm{O}=$ new operator, $\mathrm{P}=$ skill operator.

3. Do

After Go See and Think, the last step was implementation by the stakeholders. They had given the job to do section. The action was served in Table 3.

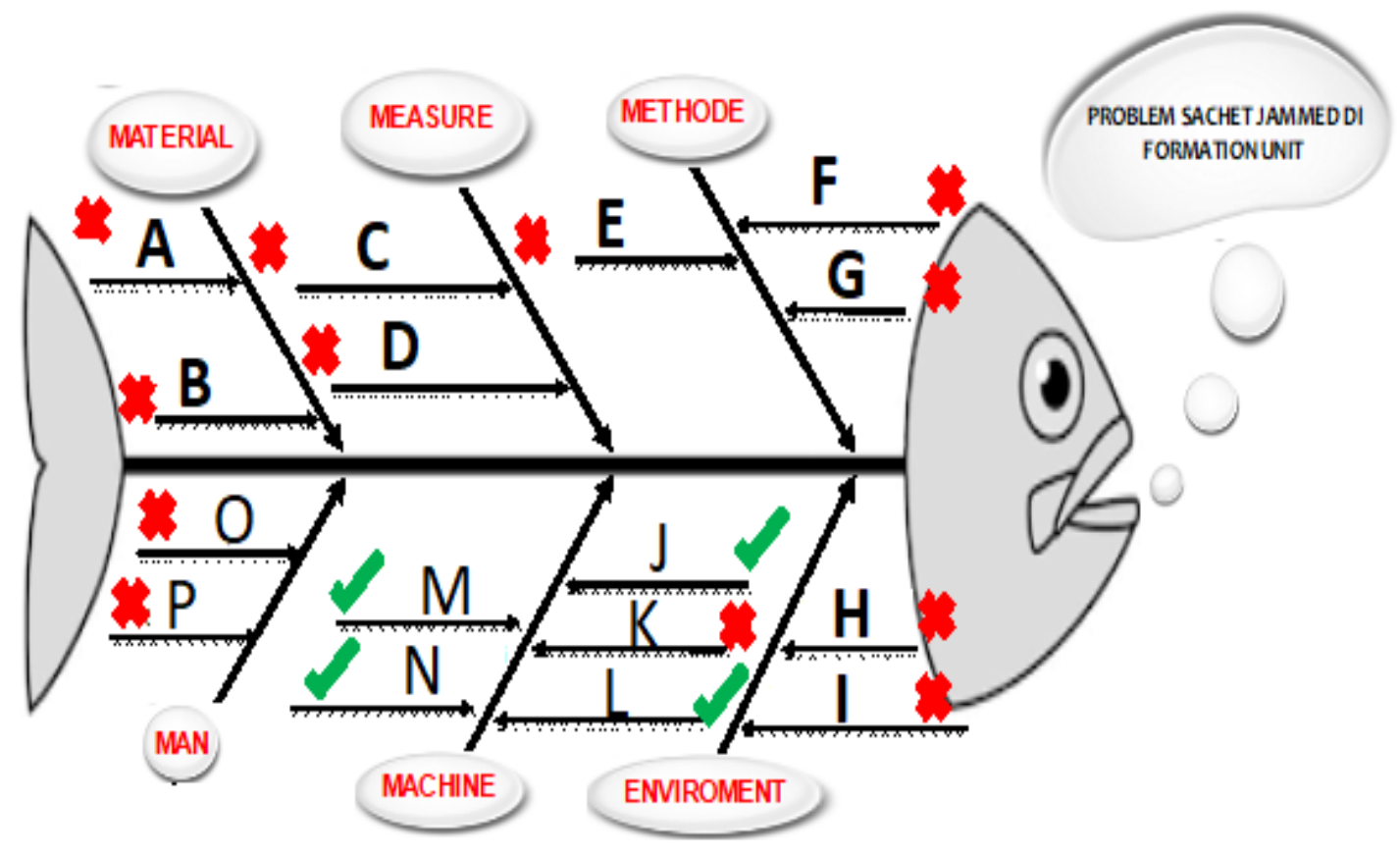

Figure 9. Fishbone of sachet jammed in formation unit through Think step. 
TABLE II

5WHY ANALYSIS OF MINOR STOPPAGES IN FORMATION 1 AND 2 UNIT - THINK STAGE

\begin{tabular}{|c|c|c|c|c|c|c|c|c|c|c|}
\hline \multicolumn{11}{|c|}{5 Why Analysis } \\
\hline \multicolumn{4}{|c|}{ 1. Start by asking WHY, answer } & \multicolumn{7}{|c|}{ 3. Circle the verified root causes } \\
\hline 2. Write & \multicolumn{2}{|c|}{$\begin{array}{l}\text { If the cause is confirmed } \\
\text { at Gemba }\end{array}$} & No & \multicolumn{4}{|c|}{ If the cause was not confirmed } & \multicolumn{3}{|c|}{$\begin{array}{l}\text { 4. Mark each root cause with a. } 1,2, \ldots \text { to link } \\
\text { action afterwards }\end{array}$} \\
\hline $\mathrm{A} / \mathrm{Q}$ & $\begin{array}{c}\text { Possible } \\
\text { Causes }\end{array}$ & Why? & $\mathrm{Y} / \mathrm{N}$ & Why? & $\mathrm{Y} / \mathrm{N}$ & Why? & $\mathrm{Y} / \mathrm{N}$ & Why? & $\mathrm{Y} / \mathrm{N}$ & Why? $\quad \mathrm{Y} / \mathrm{N}$ \\
\hline Question & $\begin{array}{l}\text { Sachet } \\
\text { left in } \\
\text { separatio } \\
\text { n unit }\end{array}$ & $\begin{array}{l}\text { Because } \\
\text { sachet often } \\
\text { stuck in tip } \\
\text { of guide } \\
\text { separation }\end{array}$ & Yes & $\begin{array}{l}\text { Because in front } \\
\text { of clamp was } \\
\text { wider than clamp } \\
\text { separation }\end{array}$ & Yes & $\begin{array}{l}\text { Because the } \\
\text { space } \\
\text { between } \\
\text { separation } \\
\text { and clamp } \\
\text { was existed } \\
\text { standard yet }\end{array}$ & Yes & $\begin{array}{l}\text { Because } \\
\text { guide } \\
\text { separation } \\
\text { was } \\
\text { changed } \\
\text { variable }\end{array}$ & \multicolumn{2}{|r|}{$\begin{array}{l}\text { Because } \\
\text { center lining } \\
\text { was existed } \\
\text { in area clamp } \\
\text { yet } \\
\text { (root cause } \\
\text { 1) }\end{array}$} \\
\hline Question & $\begin{array}{l}\text { Sachet } \\
\text { stuck in } \\
\text { finger } \\
\text { pusher }\end{array}$ & $\begin{array}{l}\text { Because the } \\
\text { tip of sachet } \\
\text { was out } \\
\text { from slide } \\
\text { guide }\end{array}$ & Yes & $\begin{array}{l}\text { Because gap } \\
\text { between slide } \\
\text { guide and } \\
\text { conveyor was so } \\
\text { higher }\end{array}$ & Yes & $\begin{array}{l}\text { Original of } \\
\text { the machine } \\
\text { fabrication } \\
\text { (root cause } \\
\text { 2) }\end{array}$ & & & & \\
\hline Question & $\begin{array}{l}\text { Sachet } \\
\text { stuck in } \\
\text { sensor } \\
\text { holes }\end{array}$ & $\begin{array}{l}\text { Because the } \\
\text { sachet was } \\
\text { slippery in } \\
\text { tip of } \\
\text { sensor }\end{array}$ & Yes & $\begin{array}{l}\text { Hole part of } \\
\text { sensor was in } \\
\text { sachet line }\end{array}$ & Yes & \multicolumn{2}{|l|}{$\begin{array}{l}\text { Because } \\
\text { initial } \\
\text { standard was } \\
\text { sensor } \\
\text { position (root } \\
\text { cause 3) } \\
\end{array}$} & & & \\
\hline Question & $\begin{array}{l}\text { The } \\
\text { sensor } \\
\text { did not } \\
\text { detect the } \\
\text { sachet }\end{array}$ & $\begin{array}{l}\text { Because } \\
\text { sensing red } \\
\text { light on the } \\
\text { sensor did } \\
\text { not touch } \\
\text { sachet }\end{array}$ & Yes & $\begin{array}{l}\text { Sensing area to } \\
\text { sachet tighten }\end{array}$ & Yes & $\begin{array}{l}\text { Because } \\
\text { sensing's } \\
\text { sensor was } \\
\text { only gone to } \\
\text { one point }\end{array}$ & Yes & $\begin{array}{l}\text { Because } \\
\text { sensor used } \\
\text { dot type } \\
\text { (point) } \\
\text { (root cause } \\
\text { 4) }\end{array}$ & & \\
\hline
\end{tabular}

TABLE III

ACTION LIST FROM CAUSE ROOTS OF MINOR STOPPAGES IN FORMATION 1 AND 2 UNIT

\begin{tabular}{cll}
\hline \hline Root Causes & \multicolumn{1}{c}{ Action List } & Who \\
\hline RC 1 & Installation centre lining in separation unit 1 and 2 & Ropikin \\
RC 2 & Modification of the gap slide guide from 12 to 5 mm & Afipudin \\
RC 3 & Close the sensor hole on first product and reposition of the sensor & Afipudin \\
RC 4 & Sensor replacement from type of sensing dot type to horizontal & Handi Koswara \\
\hline \hline
\end{tabular}

\section{G. GSTD to Minor Stoppages on Folding 1 and 2 Unit}

\section{Go See}

TABLE IV

GO SEE TO MINOR STOPPAGES IN FOLDING 1 AND 2 UNITS

Focus on the problem $(4 \mathrm{~W} 1 \mathrm{H})$

\begin{tabular}{|l|l|l|}
\hline WHAT & Problem of sachet jammed \\
\hline WHERE & Folding 1 and 2 Unit \\
\hline WHEN & $31^{\text {st }}$ Week \\
\hline Problem statement (using $4 \mathrm{~W} 1 \mathrm{H})$
\end{tabular}

Problem sachet jammed on Folding 1\&2 Unit until 31st week by ACF operator got 148 times

$$
\text { Check Points }
$$

What was the action? If the answer was $\mathrm{NO}$ and valid

write the action, who, when and status check box

Y What was the standard exist? (If yes, go to next question, if not so move to Think Do phase)

Y What did the standard follow? (If yes, go to Think Do phase, if not so go to the next point

Y Have the worker trained by this standard?

$\mathrm{Y} \quad$ Was the standard easy to understand?

Puffing of sachet checking was determined $(9-10 \mathrm{~mm} / 8$ sachets) (NO OPL : 0616-IC5-180) and auto machine operation of chain folding (6761.16.W.047-0)

Checking was done every 30 minutes by operator ACF (NO OPL : 0616-IC5-180)

Share one point lesson (OPL) to operator ACF (NO OPL : 0616-IC5-180)

OPL was given with the pictures for easy learning and directly practice

Y Was the parameter or equipment suitable into specification?

Jig tools of puff checking was suitable standard and fulfil scale to simplify the checking

148 times

Who When Status

Elyina 15th Done

Week

$\begin{array}{ll}\text { ACF } & 15 \text { th } \\ \text { Operator } & \text { Week }\end{array}$

Done

Septian July 20th Done

Septian July 20th Done

Cosmas 15th Week 


\section{Think}

Figure 10 showed that two point of possible of root cause were $\mathrm{K}$ and $\mathrm{L}$. Then, the problems were analyzed by $5 \mathrm{WHY}$ to know the truth matters in minor stoppages in folding $1 \& 2$ units. Table 5 gave data of the root causes in folding.

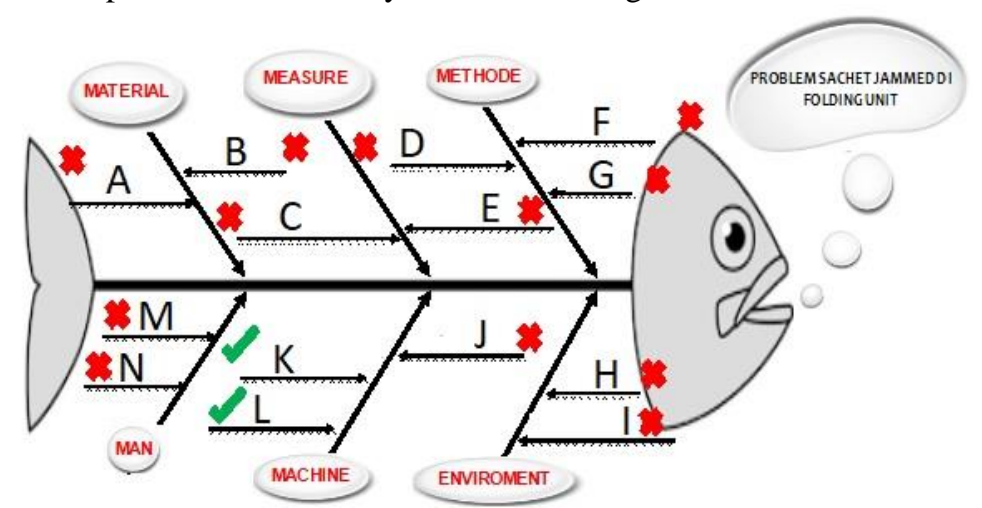

Figure 10. Fishbone of sachet jammed in folding unit through Think step.

$\mathrm{A}=$ laminate was rigid and shiny, $\mathrm{B}=$ sachet puffing was not standard, $\mathrm{C}=$ puffing device was not calibrated, $\mathrm{D}=$ installation of conveyor folding was wrong, $\mathrm{E}=$ parameter of folding unit had changed, $\mathrm{F}=$ puff checking had difference, $\mathrm{G}$ = cleaning standard was not existed yet, $\mathrm{H}=$ are of folding unit was slippery, $\mathrm{I}=$ area of folding unit was dirty, $\mathrm{J}=$ the sensor did not detect sachet, $\mathrm{K}=$ sachet stuck in drop plate, $\mathrm{L}=$ failure in folding process, $\mathrm{M}=$ new operator, $\mathrm{N}=$ skill operator.

TABLE V

5WHY ANALYSIS OF MINOR STOPPAGES IN FOLDING 1 AND 2 UNIT - THINK STAGE

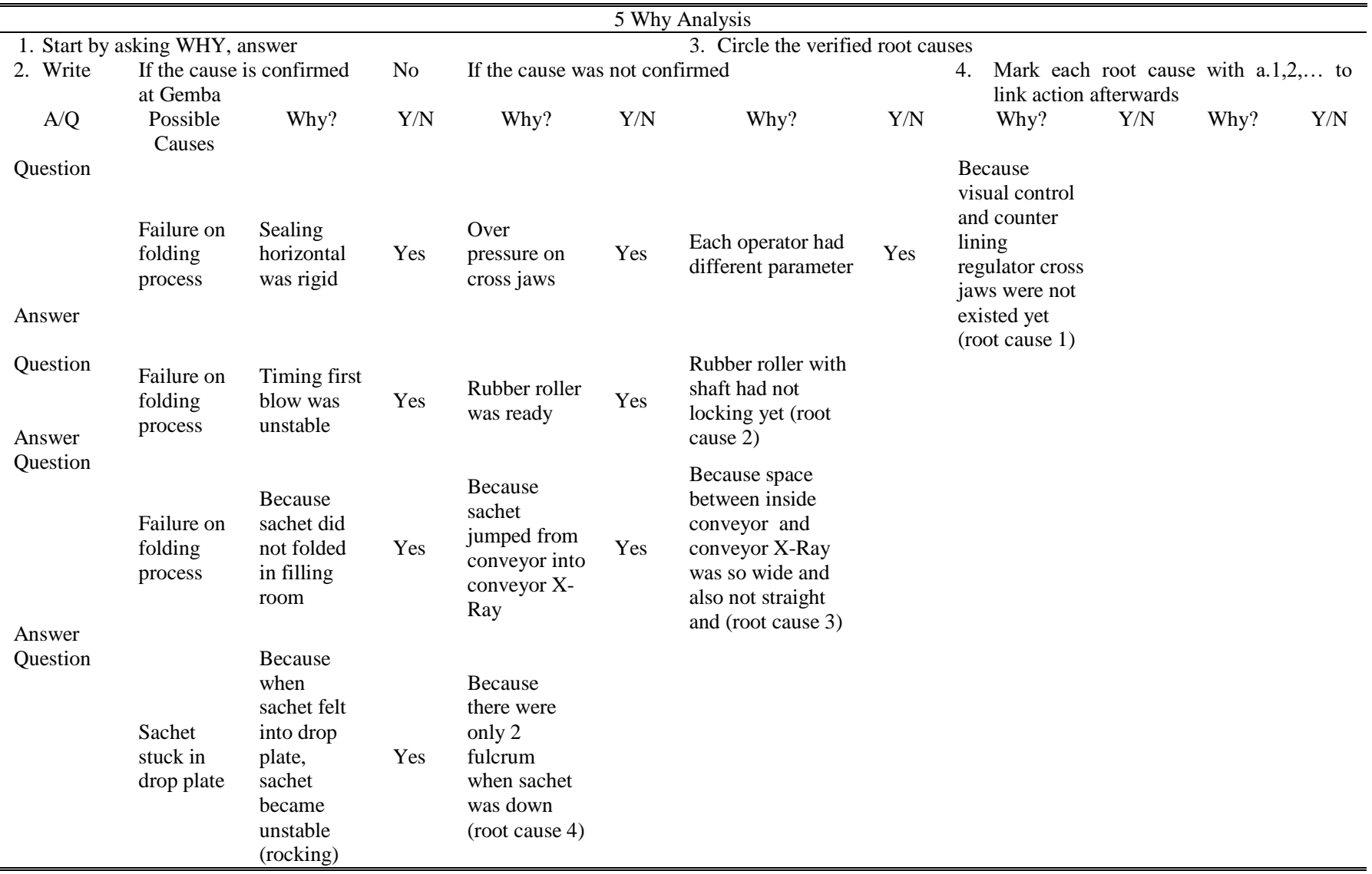

\section{Do}

Researcher from cellular company gave statement that better communication and team work must be promoted to establish autonomous maintenance teams. Report archive was arranged by the time to prepare future data analysis [6].

TABLE VI

ACTION LIST FROM CAUSE ROOTS OF MINOR STOPPAGES IN FOLDING 1 AND 2 UNIT E

\begin{tabular}{cll}
\hline \hline Root Causes & \multicolumn{1}{c}{ Action List } & \multicolumn{1}{c}{ Who } \\
\hline RC 1 & Reposition of regulator pressure cross jaws and visual control pressure & Ropikin \\
RC 2 & Making a new roller design & Cosmas \\
RC 3 & $\begin{array}{l}\text { Closing gap between inside conveyor and conveyor X-Ray, also patenting both conveyor, } \\
\text { then adding 2 roller of sachet justify }\end{array}$ & Afipudin \\
RC 4 & Making a new design of drop plate & Cosmas \\
\hline \hline
\end{tabular}




\section{H. Minor Stoppages Report After Improvement From Go See Think Do}

In Formation and Folding $1 \& 2$ Unit, the stakeholder had discussed the root causes and they were doing improvement. All progress was monitored to know success or not the action. If it was good perform so new standard was got and the company would do training and introduction to operator [7]. The action also was done in food industry as continuous improvement process [8]. This way aimed keeping result. In another hand, this chance did not work so other problems solving that more detailed used DMAIC (define, measure, analyse, improve, control) method. The evaluation was access every 10 weeks (from 32nd - 41st weeks) and it was served in Figure 11.

Figure 11 showed that significantly decreasing for index minor stoppages in SIC line 1. After improvement, score could reach lower capability, 77 index minor stoppages in 41th weeks. Based on 31 st data, the problem leaked with $79,52 \%$. It had indicated that the improvement from GSTD in Formation and Folding 1\&2 Unit 2 was completed.

$\%$ minor stoppages that reduced

$$
\begin{aligned}
& \quad=\frac{\text { minor }_{31 \text { th week }}-\text { minor }_{1 \text { st week }}}{\text { minor }_{31 \text { th week }}} \\
& \times 100 \% \\
& =\frac{(367-77)}{376} \times 100 \% \\
& =79,52 \%
\end{aligned}
$$

The researcher used manual data collection. OEE could do compilation between daily and artificial report. Both of them were headed to company future (Maran et al., 2012). Implementation was a next step to improve productivity thorough production planning and maintenance procedure [4], [9].

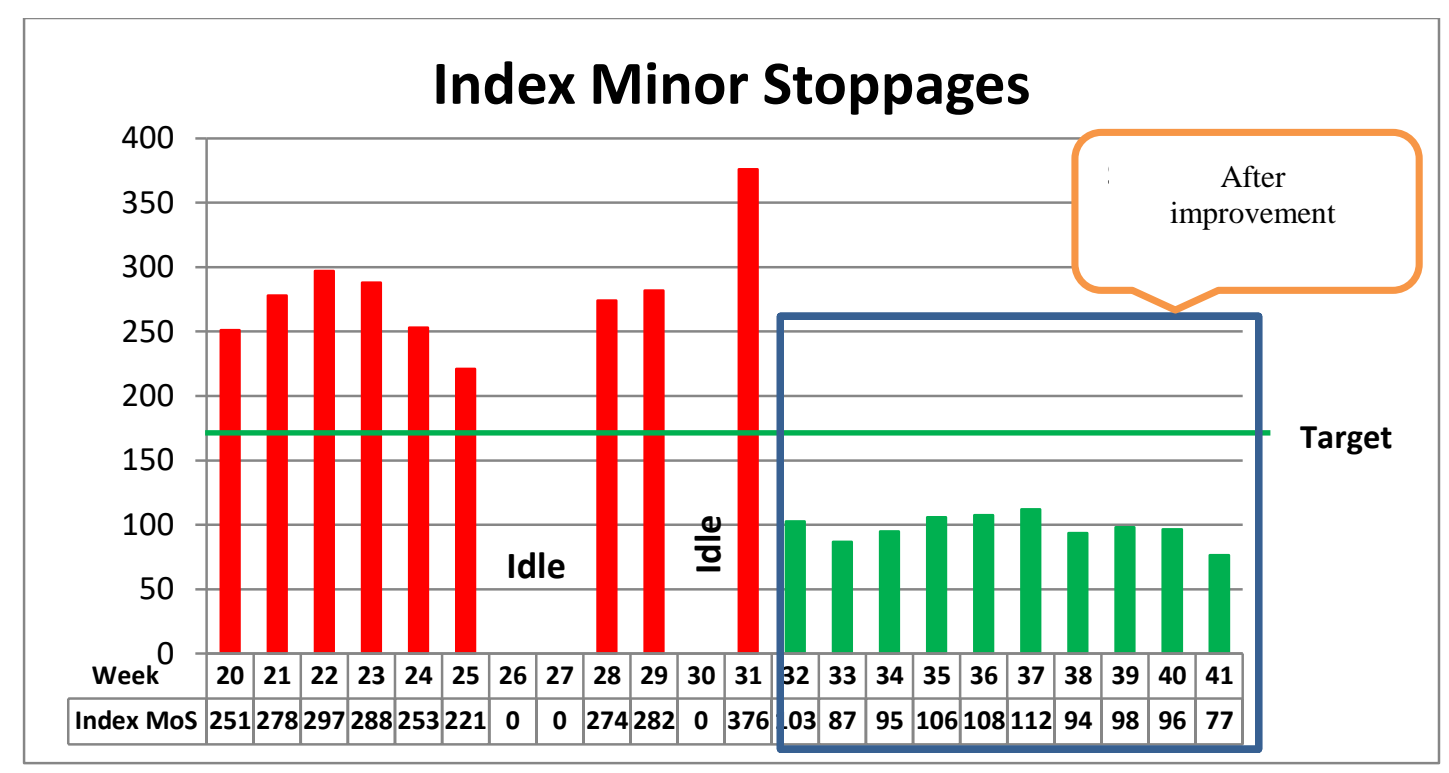

Figure 11. Index minor stoppages in SIC line 1 before and after improvement.

\section{CONCLUSION}

Based on the description, the researcher had few main points such as conditions that giving the worst perform in SIC line 1. The experiment gave losses unplanned stoppages, minor stoppages. The bigger minor stoppages were sachet jammed in Formation and Folding 1\&2 Unit. The detailed (for working of the autonomous maintenance) was founded in 31st weeks with 319 $(64,60 \%)$ and $148(29,72 \%)$ times in each series, then 519 as frequency total. Upgrading challenge that done to minimize the problems such as assembly center lining in separation unit 1 and 2, cover up of sensor holes in first product and reposition the sensor, modification gas slide guide from 12 to $5 \mathrm{~mm}$, changing sensor from sensing dot to horizontal, reposition regulator pressure cross jaws and visual control pressure, implementation a new roller design completed with locked and a new drop plate design. Applications of autonomous maintenance to handle minor stoppage were routinely investigation of machine standard (lining, cleaning, and lubrication), GSTD as problem solving, quickly respond if it founded abnormality.

\section{REFERENCES}

[1] M. K. Kholil, A. D. Maulidina, and E. Rimawan, “Analisa Total Productive Maintenance Terhadap Produktivitas Kapal/Armada Menggunakan Metode Overall Equipment Effectiveness Pada PT. Global Trans Energy International," J. Ind. Eng. Manag. Syst., vol. 9, no. 1, pp. 1-18, Mar. 2016.

[2] M. Maran, G. Manikandan, and K. Thiagarajan, "Overall Equipment Effectiveness Measurement: Weighted Approach Method and Fuzzy Expert System," in IAENG Transactions on Engineering Technologies: Special Issue of the International MultiConference of Engineers and Computer Scientists 2012, 2013, pp. 231-245.

[3] R. Singh, A. M. Gohil, D. B. Shah, and S. Desai, "Total Productive Maintenance (TPM) Implementation in a Machine Shop: A Case Study," in Procedia Engineering, 2013, vol. 51, pp. 592-599.

[4] O. Taisir and R. Almeanazel, "Total Productive Maintenance Review and Overall Equipment Effectiveness Measurement," Jordan J. Mech. Ind. Eng., vol. 4, no. Department Of Industrial Engineering, Hashemite University, Zarqa, 13115 Jordan, pp. 517522, 2010.

[5] K. Mahmood, T. Otto, E. Shevtshenko, and T. Karaulova, "Performance Evaluation By Using Overall Equipment Effectiveness (OEE): An Analyzing tool," in International Conference on Innovative Technologies 2016, 2016, pp. 6-8.

[6] G. Chand and B. Shirvani, "Implementation of TPM in cellular manufacture," J. Mater. Process. Technol., vol. 103, no. 1, pp. 149-154, Jun. 2000 
[7] M. C. Eti, S. O. T. Ogaji, and S. D. Probert, "Implementing total productive maintenance in Nigerian manufacturing industries," Appl. Energy, vol. 79, no. 4, pp. 385-401, Dec. 2004.

[8] P. Tsarouhas, "Implementation of total productive maintenance in food industry: a case study," J. Qual. Maint. Eng., vol. 13, no. 1, pp. 5-18, Apr. 2007.

[9] B. Al-Najjar and I. Alsyouf, "Enhancing a company's profitability and competitiveness using integrated vibration-based maintenance: A case study," Eur. J. Oper. Res., vol. 157, no. 3, pp. 643-657, Sep. 2004. 